\title{
Dialéctica de la investigación interdisciplinar en humanidades
}

Andrés Rodríguez

Universidad Nacional

Fecha de publicación: 22 de diciembre de 2019

\section{Resumen}

Las humanidades, como disciplinas que proponen una dialéctica con otras ciencias o conocimientos, plantean en el siglo XXI nuevos restos que son asumidos por las diferentes corrientes del pensamiento. Desde la Filosofía, hasta la Historia, pasando por la Literatura y la Teología, son campos vivos que requieren del dialogo constante entre ellas, para darles un estatuto de conocimiento irrenunciable para la sociedad.

Palabras clave: Humanidades, Dialéctica, Historia, Filosofía, Literatura, Teología, Investigación, interdisciplinariedad.

\section{Abstract}

The humanities, as disciplines that propose a dialectic with other sciences or knowledge, pose new challenges in the twenty-first century that are assumed by different currents of thought. From Philosophy to History, passing through Literature and Theology, they are living fields that require constant dialogue between them, to give them a status of knowledge that cannot be renounced by society.

Keywords: Humanities, Dialectics, History, Philosophy, Literature, Theology, Research, interdisciplinary.

\section{Introducción}

La investigación en las humanidades no es algo nuevo. Este campo de estudio ha afrontado el paso del tiempo e incluso se remonta a periodos 
clásicos de la Antigua Grecia. Ello no las hace naufragar en las corrientes mortíferas del tiempo. Por el contrario, hoy más que nunca abundan las investigaciones sobre su propuesta. Las humanidades (del latín humanitas) son un conjunto de disciplinas académicas relacionadas con la cultura humana. Existen otras denominaciones genéricas, como el concepto de «letras», que se utilizan habitualmente por oposición a las denominadas «ciencias» (debate de las dos culturas). No obstante, existen otras denominaciones cuya identificación, asociación o diferenciación con la de «humanidades» es más problemática (según la intención de quien las utilice) y que conllevan distintas consideraciones epistemológicas y metodológicas: las de «ciencias sociales» y «ciencias humanas». Se supone a las disciplinas humanísticas un mayor carácter ideográfico: el estudio de particularidades sin crear leyes o postulados generales. En su origen (los studia humanitatis del humanismo renacentista), los saberes humanísticos o letras humanas se definían por oposición a las letras divinas. ${ }^{1}$

Como elemento básico y definitorio de la civilización occidental y del sistema educativo tradicional (en este último también llegan a denominarse formación humanística), las humanidades están especialmente vinculadas a los denominados estudios clásicos: el arte y la cultura fundamentada en la Antigüedad grecorromana y que con diversas adiciones a lo largo de los siglos fue conformando el denominado canon occidental, lo que es acusado de distintos sesgos por los críticos de esta perspectiva (intelectualismo,

\footnotetext{
${ }^{1}$ EI DRAE da «humanidades» como sinónimo de «letras humanas» (literatura, y especialmente la clásica): Real Academia Española y Asociación de Academias de la Lengua Española (2014). «humanidades». Diccionario de la lengua española (23. edición). Madrid: Espasa.
} 
machismo, eurocentrismo, obsolescencia) resumidos en la expresión peyorativa dead white males («varones blancos muertos»). ${ }^{2}$

Considerar o no como "humanidades» o "ciencias sociales» a unas u otras disciplinas es un problema académico que trasciende la mera consideración organizativa o universitaria, puesto que implica la condición científica o no de unos u otros saberes (sea cual sea el alcance de tal definición, dado que el criterio de cientificidad tampoco es universalmente aceptado). Tal "cientificidad» es para algunos autores precisamente lo que no pretenden buscar los saberes que aspiran a aproximarse a la condición humana y construir la convivencia social a través del cultivo del pasado por medio del estudio filológico y hermenéutico. ${ }^{3}$

Entre las disciplinas o campos de estudio que pueden considerarse como parte de las humanidades (sin que exista un consenso generalizado en ninguna enumeración de ellas), están la filosofía ${ }^{4}$, la filología (lingüística, la semiología, la literatura, la historia de la literatura ${ }^{5}$, la crítica literaria), la historia, la geografía, el derecho, la economía, la ciencia política, la psicología, la antropología, la sociología, los estudios de arte (de artes plásticas, las artes escénicas y la música, la musicología, la estética, la teoría del arte, la crítica de arte), las ciencias de la comunicación (periodismo,

\footnotetext{
${ }^{2}$ Columbus As A Dead White European Male: The Ideological Underpinnings of the Controversy Over 1492, an essay from The World and I, The Washington Times, diciembre de 1991

${ }^{3}$ Arturo Leyte, El territorio de las humanidades. Hay que reivindicar el estudio de la cultura humana, el cultivo de lenguas, textos y objetos que nos precedieron. No con un fin arqueológico, sino con el de constituir un modelo democrático de ciudadanía, El País, 05/01/2012

${ }^{4}$ Diez Fischer, Francisco. "La hermeneutica de Gadamer como escucha tras las huellas. Una hermeneutica de lo inaparente?". Escritos 26.56 (2018): 21-61.

${ }^{5}$ Moreno, María Paulina. "El cuento de la criada, los símbolos y las mujeres en la narración distópica". Escritos Vol. 24, N. 52 (2016): 185-211.
} 
publicidad, documentación, biblioteconomía), etc. Paradójicamente, a pesar de la oposición terminológica inicial, los estudios de religión ${ }^{6}$ («divinidades»-divinities en lengua inglesa-) también se suelen considerar como parte de las «humanidades». ${ }^{7}$ Hoy en día es usualmente encontrar estudios sobre las tecnologías ${ }^{8}$ y la ética ${ }^{9}$ que están marcado tendencias.

\section{Referencias}

Pérez Vargas, Jhon y María Cabrera Vásquez. "Desafíos pedagógicos a la formación en la etapa de noviciado de comunidades religiosas." Cuestiones Teológicas Vol. 46, No. 106 (2019): 272-294. http://doi.org/10.18566/cueteo.v46n106.a04

Diez Fischer, Francisco. "La hermeneutica de Gadamer como escucha tras las huellas .Una hermeneutica de lo inaparente?". Escritos 26.56 (2018): 21-61. http://dx.doi.org/10.18566/escr.v26n56.a02

Tutor, Joaquín Darío. “Divulgación y formación en nanotecnología: un puente hacia la bioética". Escritos Vol. 24, N. 53 (2016): 483-506. http://dx.doi.org/10.18566/escr.v24n53.a12

Sarrazin, Jean Paul. "Budismo universal, budismo individual. Análisis del interés por la espiritualidad oriental en Occidente". Escritos Vol. 25, No. 54 (2017): 59-81. http://dx.doi.org/10.18566/escr.v25n54.a04

\footnotetext{
${ }^{6}$ Sarrazin, Jean Paul. "Budismo universal, budismo individual. Análisis del interés por la espiritualidad oriental en Occidente". Escritos Vol. 25, No. 54 (2017): 59-81; Turriago Rojas, Daniel. "La actitud de la Iglesia Católica colombiana durante las hegemonías liberal y conservadora de 1930 a 1953", Cuestiones Teológicas Vol. 44, No. 101 (2017): 67-94; Pérez Prieto, Victorino. “Los orígenes de la teología de la liberación en Colombia Richard Shaull, Camilo Torres, Rafael Ávila, "Golconda”, sacerdotes para América Latina, cristianos por el socialismo y comunidades eclesiales de base", Cuestiones Teológicas Vol. 43, No. 99 (2016): 73-108. Sanhueza Vidal, Kreti Soledad. "Jesucristo, prototipo de justicia y martirio, a favor de los pobres y marginados", Cuestiones Teológicas Vol. 43, No. 99 (2016): 175-197

${ }^{7}$ Tomado de: https://es.wikipedia.org/wiki/Humanidades

8 Tutor, Joaquín Darío. "Divulgación y formación en nanotecnología: un puente hacia la bioética". Escritos Vol. 24, N. 53 (2016): 483-506.

${ }^{9}$ Arango Restrepo, Pablo. "Estatuto del embrión humano." Escritos Vol. 24 No.53 (2016): 307-318.
} 
Arango Restrepo, Pablo. "Estatuto del embrión humano." Escritos Vol. 24 No.53 (2016): 307-318. http://dx.doi.org/10.18566/escr.v24n53.a04

Moreno, María Paulina. "El cuento de la criada, los símbolos y las mujeres en la narración distópica”. Escritos Vol. 24, N. 52 (2016): 185-211. ISSN 0120-1263

Pérez Prieto, Victorino. "Los orígenes de la teología de la liberación en Colombia Richard Shaull, Camilo Torres, Rafael Ávila, "Golconda", sacerdotes para América Latina, cristianos por el socialismo y comunidades eclesiales de base", Cuestiones Teológicas Vol. 43, No. 99 (2016): 73-108. https://dx.doi.org/10.18566/cueteo.v43n99.a04

Sanhueza Vidal, Kreti Soledad. "Jesucristo, prototipo de justicia y martirio, a favor de los pobres y marginados", Cuestiones Teológicas Vol. 43, No. 99 (2016): 175-197. http://dx.doi.org/10.18566/cueteo.v43n99.a08

Turriago Rojas, Daniel. "La actitud de la Iglesia Católica colombiana durante las hegemonías liberal y conservadora de 1930 a 1953", Cuestiones Teológicas Vol. 44, No. 101 (2017): 67-94. http://dx.doi.org/10.18566/cueteo.v44n101.a04 